\title{
"But Why No Women Write, I Pray?" Sarah Jinner's Defence of Women's Public Voice in Her Almanacs
}

\author{
Susana Oliveira \\ Universidade de Lisboa
}

\begin{abstract}
In seventeenth century England women writers had already been able to move beyond the two genres of writing that had initially been approved for them: translation and devotional literature. It is noteworthy, however, to acknowledge women as authors of almanacs, considering that these writings required a scientific background based upon a specific education in medicine and astrology usually inaccessible to women. Between 1658 and 1664, Sarah Jinner emerged as the first woman author of almanacs. Besides the anticipated prophecies and medical advice, this London astrologer also advocated women's public voice in her works: "But why no women write, I pray?" Jinner used these popular and widely read Early Modern English texts to publicise her defence of women. This paper focuses on Jinner's open challenge to the Aristotelian perspective on women and her defence of women's public voice.
\end{abstract}

KEYWORDS: women, almanacs, seventeenth-century England, astrology, medical advice.

You may wonder to see one of our sex in print, especially in the celestial sciences; I might urge in my defence, yea more than the volume of this book can contain: in which I am confined not to exceed ordinary bulk. $(1658: \mathrm{B} 1 \mathrm{r})^{1}$

\footnotetext{
${ }^{1}$ All of Sarah Jinner's Almanacs excerpts (An Almanack or Prognostication for the year of our Lord 1658, An Almanack or Prognostication for the year of our Lord 1659 and An Almanack for the Year of Our Lord God 1664) are taken from the facsimile edition by$$
\text { Gedert 23 (2013: 79-94) }
$$

https://doi.org/10.34136/sederi.2013.4
} 
Sarah Jinner's first words to the reader assure that, although breaking the entrenched, idealised silence expected from women, as Betty Travitsky calls it (1990:19), she will maintain both female modesty and virtue - a common defensive attitude that Elaine Hobby points out was a strategy that women of the age were bound to use so their voices could be heard: "making a virtue of necessity: a very womanly thing to do" (1988:1). Jinner further assumes, right from the beginning, the pioneering endeavour that her work represented. Although Louise Curth claims that it is impossible to determine "whether women were actually involved in compiling almanacs, perhaps under pseudonyms" before Jinner's 1658 almanac (68), the available evidence still points to Sarah Jinner as the first woman to have her name associated with the authorship of an almanac. This meant entering male territory, or rather, addressing conventional manly issues, insofar as the "celestial sciences" were concerned. In seventeenth century England, women writers had already been able to move beyond the scope of the two kinds of writing that had initially been approved, or considered suitable, for them: translation and devotional literature. It is noteworthy, then, to acknowledge women as authors of almanacs, considering that these writings required a scientific background based upon a specific education in medicine and astrology usually inaccessible to women. As Suzanne Le-May Sheffield has noted, women's admittance into scientific societies was a "slow and tortuous progression" (2006:155). In the medical field, for example, Barbara Ehrenreich and Deirdre English address the medical professionals' attitude towards women, affirming they were "actively engaged in the elimination of female healers" (2010:50), despite the fact that, as they point out, "male physicians were both more dangerous and less effective than female healers" (2010:16). With respect to midwifery, the numerous attempts to organise a professional guild were unproductive (Eales 1998:82, 83). It is also significant that the Royal College of Physicians of London had made clear, since its foundation in 1518, by a Royal Charter from King Henry VIII, that the admission of women was forbidden, a condition that would only change in 1909, when the first woman was finally admitted to the College (A. M. Cooke 1972:975, 976). Thus, in Jinner's lifetime, the Royal College of

Alan S. Weber (2002). The citations will only include the publication year and the respective page numbers. 
Physicians restricted membership to men who possessed a medical degree and had had a four years' practice, excluding unlicensed practitioners or empirics (Travitsky 1990:13). As Bernard Capp remarks, the connection between medicine and astrology "made the astrologer-physician a respected figure at the courts of kings, princes and popes" (2008:17). To become a skilled astrologer, one had to master the fields of astronomy, astrology and applied mathematics, which evidently involved years of study and training. In addition to these requirements, there was also the extra challenge of facing false accusations of witchcraft. From a historical perspective, Sarah Jinner took a major step in coming forward into the public sphere as the first woman author of almanacs.

Notwithstanding the above-mentioned reasons that substantiate a modern reader's analysis of Jinner's almanacs, another significant factor should be taken into consideration, namely the accuracy of the expression "almanac author," since almanacs contained judicial and natural astrology that were frequently the result of a compilation of other similar writings. In fact, as Adam Smyth observes, "the figure of the almanac compiler was ridiculed" and often associated with "hollow claims of learning," although certain compilers may have had a "vivid cultural presence" $(17,18)$. Hence, this common practice regarding these publications may lead the contemporary reader to question the precise extent of Jinner's authorship of the almanacs published under her name. In her study of almanacs, Louise Curth tellingly uses the expression "purportedly written by women" when referring to the topic of authorship (67). In this regard, I would like to put forward two different arguments pertaining to Sarah Jinner's authorship in this case.

First, even if one discards the sections more susceptible of compilation - for example, those regarding the astronomical tables, the general astrological information, and those containing prophecies and medical advice - Jinner's almanacs still have a distinguishing particularity when compared to other women's almanacs, such as Mary Holden's or Dorothy Partridge's, namely the personalised "To the Reader" addresses in the 1658 and 1659 almanacs. ${ }^{2}$ Here, Jinner addresses her readers directly, in a discourse

\footnotetext{
${ }^{2}$ Mary Holden's almanacs (1688 and 1689) were published thirty years after Jinner's first almanac and Dorothy Partridge's single almanac was published even later, in 1694. Louise Curth offers a stimulating account for that long intermission between the
} 
focused on women - "our business;" "our sex" (1658:B1r-B1v) intertwined with gender provocations and a humorous tone: "Though some witty coxcombs strive to put us out of conceit of ourselves;" "we will not boast of strength of body, let horses and mules do that." She further defends the importance of women in society and their rightful claim to learning; she presents a lengthy female genealogy of influence in all areas of human intellectual activity, from the political field to philosophy, physics and literature (1658:B1r-Biv). Taking all this into consideration, in my view it becomes more difficult to dismiss the striking distinctiveness of a woman's voice behind these texts speaking in defence of womanhood. Indeed, it is striking that Jinner herself signs this section with her initials, "S.J." (1658:B1v; 1659:A).

Now, focusing on the other sections of Jinner's almanacs, further evidence is found in favour of her authorship. The fact that Jinner's almanacs are clearly female-oriented is further substantiated by the comparison with the content of the almanacs published by other women, like Mary Holden and Dorothy Partridge. Jinner compiles a substantial number of ailments, recipes, advice and instructions concerning women's disorders, maladies and problems, advocating women's rights over their own bodies; this might be taken as further supporting the view that they are written by a woman. Jinner's 1658 almanac is, according to Curth, "the secondlargest collection of medical remedies" $(170)^{3}$ and in the 1659 almanac Jinner presents forty-four new recipes, all of which consider women "a major focus" (171), unlike Holden's and Partridge's almanacs, whose advice addresses male and female maladies alike. The volume of advice dedicated to women is, therefore, too significant to ignore the probability of Jinner's authorship of these almanacs. Thus, as Louise Curth points out, only Jinner's almanacs were definitely written by a woman, as opposed to those published under Mary Holden's and Dorothy Partridge's names (59). ${ }^{4}$ Bringing

publications of these three "women-authors" of almanacs, arguing that Holden's and Partridge's almanacs were not really authored by women, but published by the stationers in the hope of repeating the financial success of Jinner's first almanacs. For more on the case study of women's almanacs, see Curth (2007:67-78).

${ }^{3}$ The first being Gabriel Blunt's 1657 almanac, according to Curth's study (2007:170).

${ }^{4}$ Louise Curth raises the question of Jinner's authorship in regard to the 1664 almanac. When comparing the content of the 1664 publication with the previous ones, three inconsistencies become evident in the latter: there is no preface or any editorial 
the argument full circle, Jinner's almanacs remain a significant piece of evidence concerning Early Modern women's representativeness that ought to be explored further.

I will focus on Jinner's open challenge to the Aristotelian perspective on women, as well as on her defence of women's freedom of choice. One could argue that almanacs were not expected to contribute significantly to this matter, but I would like to stress a different point of view: Jinner did find a means to publicise her defence of women through her almanacs.

A. S. Weber's The Early Modern Englishwoman: A Facsimile Library of Essential Works, Volume 6, Almanacs is the resource through which work on Jinner is possible, since it provides access to the original texts. There are four surviving almanacs by Sarah Jinner: $A n$ Almanack or Prognostication for the year of our Lord 1658; An Almanack or Prognostication for the year of our Lord 1659; An Almanack for the year of our Lord God 1664; 5 and a fourth, from 1660, lacking a considerable portion of text. This last has two surviving copies, located in the British and Yale libraries, but it is not reproduced in facsimile version. Consequently, I will make reference only to the almanacs whose original texts are available as facsimile reproductions.

All three almanacs are octavos, which according to Capp became the "standard form" for almanacs (2008:27). Each is 40 pages in length, composed of similarly distinctive sections, which followed the conventions of male-authored almanacs, that is, they were divided in two main sections: the first part composed of the ephemeris, or astronomical tables (a detailed calendar set out as monthly tables), preceded by general astrological information; and

comment (or, as mentioned above, there is no "To the Reader" address); a different pattern in the recipes and medical advice is noticeable (most of them are recycled from the 1658 and 1659 almanacs); and there is "rather misogynistic advice," clearly absent from the previous texts (70). Other discrepancies between the almanacs of 1664 and those of 1658 and 1659 pointed out in this article might support Curth's conclusion, and despite the lack of corroborating evidence, Curth's argument is compelling. However, in the light of other studies of almanacs, such as those presented by Capp, Weber and other scholars referred to in this article, I maintain that the 1664 almanac was inspired - if not authored - by Jinner.

${ }^{5}$ The facsimile versions in Weber's volume are reproductions of the following copies: An Almanack or Prognostication for the year of our Lord 1658, at the Guildhall Library; An Almanack or Prognostication for the year of our Lord 1659, at the Huntington Library; and An Almanack for the year of our Lord God 1664, at the Edinburgh University Library. 
the second part containing the astrological prognostications or prophecies. Jinner's almanacs include a section dedicated to physical observations or medical advice and the 1658 and 1659 texts contain the address "To the Reader." The latter is a personalised and distinctive section of Jinner's almanacs, what we might consider her "hallmark" in which she addresses her readers directly in a humorous and straightforward tone.

Each text has passages in both black letter ${ }^{6}$ and roman type, a mixture of fonts which was common at the time, as Mark Bland observes, since "an average printing-house had anywhere from 15 to 25 cases of type," the most common being black letter, roman and italic (2010:109). In the 1659 text, a visible formatting mistake appears in the running-title of page B3r: "[A Prognostication] for the Year 1656" can be read instead of "[A Prognostication] for the Year 1659," an example of how the compositor distractedly inverted the position of the numeral(s) 6/9 in the box of the printing plate. Another peculiarity regarding the text format of the three almanacs is related to pagination: many pages are identified with a letter, or a letter to which is added a number, when part of the same almanac section, but a significant number of pages has no designation, which makes accurate quotation an extremely difficult task. The graceful lady portrait on the front page of the 1658 and 1659 almanacs as well as the identification of the author as a "student in astrology" constitute two other common characteristics of Jinner's texts. As Weber remarks, the "student" corresponds to our modern "scholar" (2003:363), hence emphasising the significance of Jinner's intellectual knowledge. Louise Curth further observes that emphasising one's "credentials" on the title page of the almanac was a way for authors "to create a persona for themselves as knowledgeable experienced astrologers" (73). Certainly Sarah Jinner intended to be taken seriously. That she was taken seriously and that her reputation was well known can be inferred from the fact that her two first almanacs were - as advertised on the front page - "calculated for the Meridian of London, and may indifferently serve for England, Scotland and Ireland," while her 1664 almanac was publicised, with distinctive

\footnotetext{
${ }^{6}$ Paul Shaw and Peter Brain observe that the use of the terms "Old English" and "Gothic" to refer to black letter type is often misleading and only partly accurate (1998:10). For the social and cultural meanings associated with the use of black letter versus roman type, as well as for the transition from the first type to the latter, see Stanley Morrison (1942), Charles C. Mish (1953), and Mark Bland (1998).
} 
capital letters, as an astrological calculation serving "for all EUROPE." Besides adding to the increasing author's credibility, this could also lead us to reflect upon the progressively widespread circulation of Jinner's almanacs. Elaine Hobby has also pointed out that since Jinner's almanacs continued to be published until at least 1664, one can assume that she displaces Aphra Bhen as the first woman to depend financially on her writings (1998:182). Furthermore, the army Captain Henry Herbert made reference to a Sarah Jinner as "[a] well-known practising London astrologer" in 1673 (Weber 2002:x, xi). All in all, Jinner becomes an inescapable woman author whose texts ought to be looked into.

Though ephemeral texts "discarded in December," "tailored to a year, a place and an intended audience," as Lauren Kassel notes (2011:432), almanacs reached a wide public encompassing all social and economic groups; they became the best-selling books of the midand late-seventeenth centuries, with sales, according to Capp, that "exceeded 400,000 a year in the 1660s" (2008:44). With regard to their actual readership, however, there is a much greater difficulty in providing evidence as to who bought, read and owned these publications, precisely due to their ephemeral nature. Margaret Spufford acknowledges the "obscurity" surrounding this subject (258), although she observes that a "female readership of an unknown size" - as opposed to the estimated 30 per cent of male readership - played a decisive role in stimulating the publication of ephemera, such as almanacs (22). Louise Curth further observes that "almanac writers provided clues as to the types of audiences that they were trying to reach" (79). Jinner's almanacs were clearly female-oriented and the success of her first almanac is strongly implied in "To the Reader" in the 1659 almanac, thus confirming that women were, in all likelihood, Jinner's principal readers.

Sarah Jinner's almanacs were published in London, during the Civil Wars and the Restoration. In this period of political turmoil, Jinner captivated the attention of her audience with an evocative message:

But why no women write, I pray? Have they not souls as well as men? Though some witty coxcombs strive to put us out of conceit of ourselves as if we were but imperfect pieces, and that nature, intending a man, when the seminal conception proves weak there issues a woman. (1658:Bir) 
Behind Jinner's open challenge to the patriarchal system lies a very complex and troubling belief that held women to be inferior human beings, as asserted in the renowned anonymous tract, most certainly familiar to Jinner, Disputatio nova contra mulieres. Through the rhetorical question, Jinner further implies the answer to the debate on the topic of whether or not women have souls. Jinner is plainly confronting the feminine archetypes proclaimed by the scholastic theological and philosophical frame of thought, which regarded woman as an incomplete version of the male, an imperfect and deformed man, or, as stated in Aquinas' defence of the Aristotelian idea, "the female is a misbegotten male," "produced incidentally and beside the intention of nature" (1921:190-191). Although a contextualised and detailed analysis of both Aristotle's and Aquinas' texts in their original languages may lead to other readings - rather more sympathetic towards women, in fact, as proposed by Michael Nolan $^{7}$ - we can detect in Jinner some similarities with the same "feminist" light still predominant in gender studies. In fact and to a considerable extent, Jinner anticipates the critiques that Simone De Beauvoir and other contemporary authors, make of those same Aristotelian and Aquinean (mis)conceptions of women (1997:15,16).

Additionally, Jinner is also directing the reader to the everpresent debate regarding women and woman's responsibility for the fall. According to the Jewish-Christian Bible, and subsequently to the concordance of the Fathers of the Church and the scholastic community, Eve was considered more responsible for the original sin than Adam. Moreover, as Tertullian argued, each woman should be considered another Eve and therefore the inheritor of her sin and guilt (2004:3). In addition, Saint Paul had plainly indicated that all women should "learn in silence with all subjugation" (First Epistle to Timothy 2:11-14). Not only does Jinner resolve to "break the entrenched silence," as previously mentioned, but significantly she also chooses to address openly a sensitive gender topic in order to subvert it, and she does so in an antagonistic tone to further urge her readers to (re)act against the prevailing male attitude towards women.

7 Nolan has written extensively on the "myths" and misconceptions vis-à-vis Aristotle's and Aquinas' texts regarding women (1993; 1999). 
Then, Jinner turns to a more inspirational and supportive rhetorical approach:

But know that Aristotle affirms that women doth contribute to formation matter as well as place. Mankind is preserved by women, many other rare benefits the world repeath by women, although it is the policy of men to keep us from education and schooling, wherein we might give testimony of our parts by improvement: we have as good judgement and memory, and I am sure as good fancy as men, if not better. (1658:Bir)

As Ian Maclean observes, in Aristotle's dichotomic interpretation of men's and women's existence, men are associated with active and formative characteristics, while women are "passive, material and deprived, desiring the male in order to become complete" (1980:7). In this context, Jinner chooses a conciliatory approach and avows to her readers that women play an important role within the framework of Aristotelian thought after all, since women provide (hu)mankind with both existence and completeness. Subsequently, in a rather humorous way, Jinner appeals to female agency and urges women to cherish their key role in humanity, to think highly of themselves, regardless of male-imposed constraints. She encourages women to focus on their qualities and potential accomplishments - not on their faults or under-achievements. Although Jinner mentions that men's policy is to deprive women of education, she is almost certainly referring to women's lack of access to classical medical learning in universities. In fact, the institutionalised attempt to maintain man's monopoly over Latin and Greek medical knowledge was "[the] only distinguishing advantage of the university-trained physician, and the sole claim to his medical superiority and high fees" (Weber 2003:368, 375). In this context, Jinner's use of Latin in the "Physical Observations" of 1664 is significant, since the inclusion of that particular element associates her work with the authority conferred by and through classical knowledge and indicates the rising status of her scholarship. It can be further demonstrated that Jinner's comment on women's impediments in schooling is not to be generally applied by the fact that she addresses her work to a female audience, hence exploiting the growth in women's literacy and education. This is underscored when she praises women writers of the time - Margaret Cavendish, Katherine Philips, and Elizabeth Grey (1658:B1r-B1v), whose collection of medical recipes had been published in 1651, with 
several additional reprints, under the title A Choice Manual, or Rare Secrets in Physic and Surgery.

As previously mentioned, in this 1658 "To the Reader" address Jinner inspires women to flourish and succeed by presenting a mesmeric inventory of women's names, whose achievements in the various fields of the public sphere might be followed: the Amazons, Semiramis, Tomiris, Queen Elizabeth Tudor, Elizabeth Grey, Margaret Cavendish, Catherine Philips, and even, as Jinner puts it, "a pope of our sex, named Pope Joan, [whose existence] the best historians do not deny" (1658:B1r-B1v). Again, Jinner is suggesting that women should place themselves outside the "mainstream" archetypal models of conduct assigned to them: passivity, submission, silence. Jinner is actually offering her readers the possibility to pause and ponder on the numerous examples of women who decided against feminine dependence and broke free from patriarchal dominance. It is possible for a woman to show she is on the same level as men, to perceive herself as the authority, not only over herself, but also over her family, or even the political and religious forces of a nation. After all, "Pope Joan," Queen Elizabeth, the Amazons, and the others listed by Jinner did so. These examples are then the ancestors of Jinner's readers', a matriarchal family tree that is, as the author construes, women's decision to create. If a woman's true vocation is not submission, then she must overcome the ideological discourses that bind her to the private sphere, and claim her place and role in the public domain. In the light of Terry Eagleton's observation that "there is indeed an internal relation between being a woman (a social situation) and being a feminist (a political position)" (211), Jinner's advocacy of women's public voice is evident in her forward-thinking "feminist" discourse.

Significantly, the corollary of Jinner's proposed matriarchal lineage is Queen Elizabeth I. In a rather scornful tone, she explains why England was going through such difficult times:

When or what Commonwealth was ever better governed than this by the virtuous Queen Elizabeth? I fear me I shall never see the like again, all you princes nowadays are like dunces in comparison of her: either they have not the wit she had or the honesty she had: something is the matter that things do not fadge so well! (1658:Bir) 
Here, Jinner connects past, present and future, adopting a more political tone and opposing the Queen's political and personal excelling qualities to the current political governors' inability and lack of moral values, allowing the reader to infer that the current situation is unlikely to be improved with new leadership of the commonwealth. Although Jinner was no "sectary" (Hobby 1988:182), she assumes and promotes a political public voice for women in passages like this one throughout her almanacs. Capp refers to Jinner's vigorous social and political commentary, suggesting that she held an anti-authoritarian position (2008:87). In fact, in her 1659 almanac, she predicts in the astrological observations for July that "from all parts we hear of desperate unreconcilable wars" (1659: $\mathrm{C} 2 \mathrm{v}$ ); then, under the astrological observations for October she states that although she wishes no uprising, she admits "that a people are not bound to obey well, when governors do not govern well" (1659:C $3 r$ ). Later on, in the astrological observations for November she urges, "Come let us all amend, the world is bad enough," and, after mentioning the King of Spain, the French and the Dutch, she ends up her considerations in London, whose politicians she describes as "mare makers of discontent" (1659:C3V). Jinner's ideological and political affiliations during this troubled period might also be inferred by her choice of publisher: all her almanacs were printed by John Streater for the Company of Stationers. Streater was an English soldier, pamphleteer, and political writer in the 1650 s, openly hostile to Oliver Cromwell. As Jason Peacey notes, Streater was a "key republican critic of the regime, whose works had attracted the attention of the authorities" (2004:200). According to Joad Raymond and Nigel Smith, Streater represents "the turning of the Leveller diaspora into the classical tradition to produce a genuine popular republicanism" (Raymond 1998:567-574; Smith 1995:137-155). This information may contribute to a deeper and clearer understanding of her political beliefs and observations. Jinner was politically aware and active; as a woman writer she inspired her counterparts to adopt a similar mind-set towards the strangest of times in which they were living. Jinner's attitude confirms Susan Wiseman's observation that despite women's exclusion from the political sphere, they "consistently influenced the discourse on and of politics" (2006:9), to which category we might therefore add Jinner herself. 
Another important and significant element of these almanacs is Jinner's dispensation of medical advice. Although she also provides such advice for men, her recipes are female-oriented and concentrate on women's concerns with conception, pregnancy and numerous infections, as well as recipes for women's cosmetics, for example how "to take away pimples" or how to "make the skin fair and shining" (1664:B7v). Jinner does not exclude psychological considerations concerning women's welfare, providing remedies for "the corrupt humors" as well as for the "prevention of quarrels between Men and Wife," for example (1659:B8r; 1664:B7r). She also provides instructions for potions that "provoke the Terms," for the "further conception in a woman," to "expel a dead child," to "dry up the milk," and to "take away the desire of a woman to the Act of Venery" (1558:B5r-B8v; 1559:B4r-B8v; 1664:B3r-B8r): all medicallyrelated concerns for women, who were - and, generally speaking, still are - considerably more distressed and burdened regarding sexually-related issues than men. In this respect, one might consider the specific issue of abortion. Jinner's recipes to "provoke the terms" (menstruation) or "to expel a dead child" contained abortifacients pennyroyal and mugwort (1658:B5r,B5v; 1659:B6r; 1664:B3r). Although early modern practitioners were ambivalent about the practice of abortion (Evelyne Berriot-Salvadore 2000:348-349) they knew that women might use the remedies provided in a certain context to suit their needs in a quite different way. As Chantelle Thauvette notes:

Regardless of whether Jinner's readers actually used Jinner's recipes to abort or induce premature labor, we may conclude that the combination of watching the calendar and recipes gave women options in managing their own reproductive and menstrual cycles without having to subject themselves to scrutiny from a culture likely to link any gynaecological ailment to a woman's sexual (mis)conduct. (2010:246)

Thus, more than ephemera to be discarded at the end of the year, Jinner's almanacs might have functioned as a practical reference and advice book for women to achieve a degree of freedom of choice over their reproductive lives.

Jinner's almanacs were, therefore, deeply focused on a female audience for which they were in large part intended, taking into serious account women's wellbeing as a whole: the physical, the psychological and the intellectual condition of her female readers 
was a dominant concern. Moreover, Jinner addressed these wideranging matters in a discourse in the 1658 almanac that may have appeared to some as rather too clear and open, for in the following year's almanac Jinner declares: "Therefore this year, I here present you with some other of the like nature [predictions; physical cures], avoiding such language, as may, perhaps be offensive to some" (1659:B1r). Once again, the question of women's display of modesty and virtue was at stake, even more so since the language associated with gynaecology, conception, breast-feeding and other sexualrelated matters might be considered too explicit and offensive. Jinner did, nevertheless, underline the main purpose of her advice, emphasising the consequences of taking modesty in the medical field too seriously: "It is not fit the world should be deprived of such helps to Nature; for [...] many, by their Modesty, suffer much" (1659:B1r). By referring to women's physical matters in plain English, Jinner provided her readers with a certain type of knowledge they might not obtain otherwise, be it through the medical authorities Jinner used as her sources or through the reading she recommends, like Levinus Lemnius's 1559 The secret miracles of nature (1659:B1r). She further states that her main aim is "that our sex may be furnished with knowledge: if they [women] knew better, they would do better" (1659:Bir).

Sarah Jinner thus offers a feminine public voice for the seventeenth century, perhaps even in some respects a forwardthinking "feminist," as we might be inclined to call her today. Towards the conclusion of her 1658 "To the Reader" address, Jinner reiterates the underlining message that may be perceived in all her almanacs, namely a captivating and inspirational assertiveness promoting the harmony of the spheres through women's action: "Let us scour the rust off by ingenious endeavouring the attaining higher accomplishments [...] so by this means we should have an excellent world [...] Farewell till next year" (1659:B1v).

\section{References}

Aquinas, Thomas 1921. Summa theologica. Third Part (Supplement). Trans. Fathers of the English Dominican Province. London: Burns Oates \& Washbourne.

Bland, Mark 2010. A Guide to Early Printed Books and Manuscripts. Malden and Oxford: Wiley-Blackwell. 
S. Oliveira

— 1998. "The Appearance of the Text in Early Modern England." Eds. W. Speed Hill and Edward M. Burns. Text: An Interdisciplinary Annual of Textual Studies, Volume 11. Michigan: University of Michigan Press: 91155.

Berriot-Salvadore, Evelyne 2000 (1993). "The Discourse of Medicine and Science." Eds. Natalie Davis and Arlette Farge. A History of Women in the West: Renaissance and Enlightenment Paradoxes. Cambridge and London: Harvard University Press: 348-388.

Capp, Bernard 2008 (1979). Astrology and the Popular Press: English Almanacs 1500-1800. London: Faber and Faber.

Cooke, A. M. 1972. A History of the Royal College of Physicians of London: Volume III. Oxford: Clarendon Press.

Curth, Louise Hill 2007. English Almanacs, Astrology and Popular Medicine: 1550-1700. Manchaster and New York: Manchester University Press.

De Beauvoir, Simone 1997 (1949). The Second Sex. Trans. and Ed. H. M. Parshley. London: Vintage.

Eales, Jacqueline 1998. Women in Early Modern England: 1500-1700. London: University College London Press.

Ehrenreich, Barbara and Deirdre English 2010 (1973). Witches, Midwives, and Nurses: A History of Women Healers. New York: Feminist Press.

Habermas, Jürgen 1991. The Structural Transformation of the Public Sphere: An Inquiry into a Category of Bourgeois Society. Trans. Thomas Burger. Cambridge: MIT Press.

Hobby, Elaine 1988. Virtue of Necessity: English Women's Writing 1649-88. London: Virago Press.

Kassel, Lauren 2011. "Almanacs and Prognostications." Ed. Joad Raymond. The Oxford History of Popular Print Culture Volume One: Cheap Print in Britain and Ireland to 1660. Oxford: Oxford University Press: 431-442.

Maclean, Ian 1980. The Renaissance Notion of Woman: A Study in the Fortunes of Scholasticism and Medical Science in European Intellectual Life. Cambridge: Cambridge University Press.

Mish, Charles C. 1953. "Black Letter as a Social Discriminant in the Seventeenth Century." PMLA 68: 627-630.

Morrison, Stanley 1942. "Black-letter" Text. Cambridge: Cambridge University Press.

Nolan, Michael 1999. Aquinas' Philosophy of Man and Woman. Dublin: Four Courts Press. 
— 1993. "The Mysterious Affair at Mâcon: The Bishops and the Souls of Women." New Blackfriars 74/876: 501-507.

Peacey, Jason 2004. Politicians and Pamphleteers: Propaganda During the English Civil Wars and Interregnum. Hampshire and Burlington: Ashgate.

Raymond, Joad 1998. "John Streater and the Grand Politick Informer." The Historical Journal 41/2: 567-574.

Shaw, Paul and Peter Brain eds. 1998. Blackletter: Type and National Identity. New York: Princeton Architectural Press.

Sheffield, Suzanne Le-May 2006 (2004). Women and Science: Social Impact and Interaction. Santa Barbara: Rutgers University Press.

Smith, Nigel 1995. "Popular republicanism in the 1650s: John Streater's "Heroick Mechanicks." Ed. David Armitage. Milton and Republicanism. Cambridge: Cambridge University Press: 137-155.

Smyth, Adam 2010. Autobiography in Early Modern England. Cambridge: Cambridge University Press.

Spufford, Margaret 1981. Small Books and Pleasant Histories: Popular Fiction and its Readership in Seventeenth-Century England. Cambridge: Cambridge University Press.

Tertullian 2004. On the Apparel of Women. Trans. Rev. S. Thelwall. NP: Kessinger Publishing.

<url: $\quad$ http://books.google.pt/books?id=geOoHJBUygwC\&q=eve\#v= snippet\&q=eve\&f=false $>$. Last accessed 18/04/2013.

Thauvette, Chantelle 2010. "Sex, Astrology and the Almanacs of Sarah Jinner." Early Modern Women: An Interdisciplinary Journal 5: 243-249.

Travitsky, Betty 1990. "Placing Women in the English Renaissance." Eds. Anne M. Haselkorn Betty Travitsky. The Renaissance Englishwoman in Print: Counterbalancing the Canon. Amherst: University of Massachusetts Press: $3-44$.

The Holy Bible 2003 (1611). Authorized King James Version. NP: Thomas Nelson, Inc.

Weber, Alan S. ed. 2002. The Early Modern Englishwoman: A Facsimile Library of Essential Works, Series II, Printed Writings, 1641-1700: Part I, Volume 6, Almanacs. Aldershot: Ashgate.

— 2003. "Women's Early Modern Medical Almanacs in Historical Context." English Literary Renaissance 33/3: 358-402. 
S. Oliveira

Wiseman, Susan 2006. Conspiracy \& Virtue: Women, Writing and Politics in Seventeenth-Century England. Oxford and New York: Oxford University Press.

How to cite this article:

Oliveira, Susana. "'But Why No Women Write, I Pray?' Sarah Jinner's Defence of Women's Public Voice in Her Almanacs." SEDERI 23 (2013): 79-94.

Author's contact: spoliveira17@gmail.com

Submission: 29/10/2012 - Acceptance: 20/05/2013 